OPEN ACCESS

Vol. 7, No. 2, Oktober, 2019

Page. $44-96$

DOI: https://doi.org/10.21107/jaffa.v7i2.6425
JOURNAL OF AUDITING, FINANCE, AND FORENSIC ACCOUNTING (JAFFA)

E-ISSN: 2461-0607 ISSN: 2339-2886

https://journal.trunojoyo.ac.id/jaffa/index

\title{
THE MEDIATING EFFECT OF TIME BUDGET PRESSURE ON BEHAVIORAL DECLARATION OF AUDIT
}

Edwin Setiawan, Andreas, Novita Indrawati, Hardi

Master of Accounting, Postgraduate Program, University of Riau

\section{Article Info:}

Received: 22 July 2019

in revised form: 11 September 2019

Accepted: 24 September 2019

Available Online: 13 Januari 2020

\section{Keywords:}

Decreased Audit Quality Behavior, Time Budget Pressure, Internal Locus Of Control, External Locus Of Control, Organizational

Commitment

Corresponding Author:

Email:

edwinsetiawanwardana@gmail.com
Abstract; This study aims to test and analyze the behavior of audit quality deterioration by integrating the characteristics of individual auditors (locus of control and organizational commitment) with time budget pressure. The study was conducted by survey method by distributing questionnaires to auditors who worked at KAP in the Provinces of West Sumatra, Riau and Riau Islands. The sampling technique uses the purpose sampling method. The questionnaire that can be used totaling 60 questionnaires. Data analysis using wrapPLS 6.0. The results showed that internal locus of control had a negative effect on time budget pressure and decreased audit quality behavior, external locus of control had a positive effect on time budget pressure and decreased audit quality behavior, organizational commitment negatively affected time budget pressure and decreased audit quality behavior, and time budget pressure has a positive effect on audit quality deterioration behavior, and time budget pressure mediates the influence of locus of control, organizational commitment to audit quality deterioration.

Abstrak; Penelitian ini bertujuan untuk menguji dan menganalisis perilaku penurunan kualitas audit dengan mengintegrasikan karakteristik auditor individu (locus of control dan komitmen organisasi) dengan tekanan anggaran waktu. Penelitian dilakukan dengan metode survei dengan menyebarkan kuesioner kepada auditor yang bekerja di KAP di Provinsi Sumatera Barat, Riau dan Kepulauan Riau. Teknik pengambilan sampel menggunakan metode purpose sampling. Kuesioner yang dapat digunakan berjumlah 60 kuesioner. Analisis data menggunakan wrapPLS 6.0. Hasil penelitian menunjukkan bahwa locus of control internal memiliki efek negatif pada tekanan waktu anggaran dan penurunan perilaku kualitas audit, locus of control eksternal memiliki efek positif pada tekanan waktu anggaran dan penurunan perilaku kualitas audit, komitmen organisasi berpengaruh negatif terhadap tekanan waktu anggaran dan penurunan audit perilaku kualitas, dan tekanan waktu anggaran memiliki efek positif pada perilaku penurunan kualitas audit, dan tekanan waktu anggaran memediasi pengaruh locus of control, komitmen organisasi terhadap penurunan kualitas audit. 


\section{INTRODUCTION}

Audit procedures that are well designed and implemented will provide good results, thus increasing user confidence. The trust of users of audited financial statements to the public accounting profession is very dependent on the quality of the audit produced by the Public Accounting Firm (KAP). Audit quality is the probability that the auditor can find and report errors and irregularities that occur in audited financial statements (DeAngelo, 1981). The phenomenon that occurs in auditor deviation behavior which results in a decrease in audit quality such as the CPAB inspection results (Canadian Public Accountability Board) listed in the 2015 Public Report on Annual Inspections of Quality of Audits in Canada shows that there are still inconsistencies in audit quality throughout the company " The Big Four "so that it needs an improvement in the quality control system in the four companies. CPAB found 24 files that had significant findings from 93 files that were inspected, far improved compared to 2014 which were only 7 from 98 files (cpab-ccrc.ca, 2016).

The International Forum of Independent Audit Regulators (IFIAR) states that the tempo of audit quality improvement is very slow and calls for measurable improvements in 2019. IFIAR also mentions that the areas with the most deficiencies when audit inspections are at the core of the financial report audit itself (ifiar.org, 2016). The decline in global audit quality is certainly not to be ignored. All KAPs, including "The Big Four", need to make changes and improve audit quality control systems with approaches at various levels (multilevel approach). As in the case of KAP J, A, S \& Rekan in 2015, through the Minister of Finance Decree (KMK) Number: 445/KM.1/ 2015. Determination of the license freeze sanctions based on Minister of Finance Regulation No. 17 / PMK.01 / 2008 concerning AP B A Public Accountant Services, $\mathrm{CPA}$, is subject to freezing sanctions for 6 months because the concerned party has not fully complied with the Audit Standards (SA) - Public Accountant Professional Standards (SPAP) in carrying out general audits of PT. 2013 BCP fiscal year (http://pppk.kemenkeu.go.id/News/Details/22). Audit quality reduction behavior is a serious threat to audit quality because audit evidence collected during the implementation of audit procedures is not sufficient as an adequate basis for auditors to express opinions regarding the fairness of audited financial statements (Otley and Pierce, 1996; Herrbach, 2001). Unethical behavior by individuals in organizations can be caused by personal characteristics, situational or interaction between these factors (Trevino, 1986).

Locus of control describes the level of a person's beliefs about the extent to which they can control the factors that influence the success or failure they experience (Rotter, 1966). Someone who believes in the success or failure experienced in his control is called having an internal locus of control, while those outside his control are called having an external locus of control (Nugraha, 2016).

Jayanti (2017); Nugraha (2016); Sudirjo (2013); Gustati (2012), proves that locus of control has a positive effect on audit quality reduction behavior, and Wintari (2015) proves that locus of control has a negative effect on audit quality decline behavior. In contrast to Diana's (2016) research, proving that locus of control does not affect the behavior of audit quality decline. Besides locus of control, another personal characteristic used in this study is organizational commitment.

Audit quality decline behavior and time budget pressure can be influenced by personal characteristics, auditors who have organizational commitment will have a better level of loyalty and are more willing to do work than what should be done (Irawati et al., 2005). Organizational commitment is the level at which a worker identifies an organization, its goals, and hopes to remain a member (Robbins and Timothy, 2015).

Wijayanti (2009); Triono et al. (2012); Aisyah et al. (2014) and Nugraha (2016) show organizational commitment has a negative effect on acceptance of audit behavior. The high organizational commitment will minimize the desire to move to work which will have an impact on the low acceptance of auditor dysfunctional behavior. Unlike Harini et al. (2010) which shows that organizational commitment does not have a direct relationship with audit dysfunctional behavior they are in KAP (Nugraha, 2016).

Time budget pressure has a positive effect on dysfunctional behavior (Simanjuntak, 
2008; Nadirsyah and Zuhra, 2009; Kurnia, 2009; Silaban, 2009; Manullang, 2010; Tanjung, 2013; Sudirjo, 2013; Kholidiah and Murni, 2014; and Nugraha, 2016) shows the higher time budget pressure perceived by the auditor in the implementation of the audit program, the increasing the tendency for auditors to take dysfunctional actions (Otley and Pierce, 1996). Time budget pressure becomes a mediating variable in this study, which mediates the influence of locus of control and organizational commitment on audit quality deterioration behavior. Previous studies that used audit time budget pressure as a mediating variable in the influence of auditor personal characteristics on audit behavior were Silaban (2009); Sudirjo (2013); and Nugraha (2016).

\section{LITERATURE REVIEW AND HYPOTHESES DEVELOPMENT}

\section{Attribution Theory}

Attribution theory studies the process of how someone interprets an event, reason or cause of behavior. Attribution theory was developed by Fritz Heider in 1958 which argues that a person's behavior is determined by a combination of internal forces, namely factors that originate within a person, and external forces, namely factors that originate outside of someone (Suartana, 2010) .

\section{Job Stress Model Theory}

Stress is a condition that emphasizes one's self and soul beyond its limits, so that if it continues to be left without a solution, this will have an impact on his health. Stress does not just arise, but the causes of stress arise generally followed by factors that affect a person's psyche, and events that occur outside of his ability so that the condition has emphasized his soul (Fahmi, 2014).

\section{Audit Decreasing Behavior}

Auditor behavior is an important factor that influences audit quality produced by KAP. Auditor behavior that reduces audit quality directly or indirectly is called audit dysfunctional behavior. Audit dysfunctional behavior consists of audit quality reduction behavior and underreporting of time behavior (Kelley and Margheim, 1990; Otley and Pierce, 1996). Behavior can be defined as a reaction that someone has towards everything that is seen, felt, and understood to subsequently be formed in actions and attitudes. In the context of behavioral science, it is explained that everyone has different views in assessing and understanding each situation especially if it is poured out with the background (background) that he has lived. The application is depicted in every decision made, including that decision can have an influence on the organization where he is sheltered (Fahmi, 2014).

\section{Time Budget Pressure}

The pressure experienced by the auditor at the time of the audit because of the limited time allocated to carry out all audit tasks is called time budget pressure. The auditor will feel the time pressure when carrying out the audit program due to the tight budget allocated audit time or an imbalance between available audit time budgets and real time needs to complete the overall audit program (Kelley and Seiler, 1982). When an auditor experiences pressure because of the tight audit time budget, the auditor's response is likely to be functional and dysfunctional (De Zoort and Lord, 1997). The functional way is that auditors behave as well as possible and use time as effectively as possible (Wintari, 2015).

\section{Locus of Control}

Locus of control is defined as the individual's belief in the ability to control fate (destiny) itself (Kreitner and Kinicki, 2005). Locus of control is one of the personality variables. Personality is the total number of ways in which an individual acts on and interacts with others (Robbins and Timothy, 2015). Someone who believes in the success or failure experienced in his control is called having an internal locus of control, while those outside his control are called having external locus of control (Lefcourt, 
1982). Locus of control plays a role in motivation, different locus of control can reflect different motivations and different performance. In general, individuals who have internal locus of control view events or experiences as interrelated and they learn from repeated experiences, while individuals who have external locus of control tend to view an event or experience not related to the next event and they do not learn from experience (Nugraha, 2016).

\section{Organizational Commitment}

According to Robbins and Timothy (2015) organizational commitment is a feeling of association or psychological and physical attachment of the employee where he works or the person where he is a member. Another definition, organizational commitment is the level at which a worker identifies an organization, its goals, and hopes to remain a member (Nugraha, 2016). Organizational commitment creates the power to balance dysfunctional tendencies (Triono et al., 2012). As commitment increases, organizations are not seen as enemies and manipulation is not needed to get what they want. Someone who has a strong belief in the organization and is willing to work hard to achieve organizational goals, will accept less dysfunctional behavior to achieve personal goals (Triono et al., 2012).

\section{Effect of Locus of Control on Audit Quality Decreasing Behavior}

Wintari (2015) states that individuals with internal locus of control put primary responsibility in their own hands, what happens to them is greatly influenced by their own actions. Auditors with internal locus of control feel what is happening to their lives because of their own efforts, so the auditor will improve the quality of his work for the better. In the context of auditing, the act of manipulation or fraud will manifest in the form of dysfunctional behavior, namely a decrease in audit quality. This behavior means that the auditor will manipulate the auditing process to achieve individual performance goals. Reducing the quality of auditing can be produced as a sacrifice that the auditor must make to survive in the audit environment. This behavior will occur in individuals who have external locus of control.

The influence of locus of control on audit quality reduction behavior is based on attribution theory, which states that a person's behavior is determined by a combination of internal strength and external power. Locus of control is an internal force that influences a person's behavior. Individuals who have external locus of control are individuals who believe that they cannot control events and results. External locus of control is the feeling experienced by individuals that their behavior is determined by factors outside their control. Thus, it can be hypothesized as follows:

H1a: Internal locus of control has an effect on audit quality decline behavior.

H1b: External locus of control has an effect on audit quality decline behavior.

\section{Effect of Organizational Commitment on Audit Quality Decreasing Behavior}

A person's commitment to his profession is manifested in three characteristics such as the following: an acceptance of the goals and values of the profession, a willingness to make an effort as strong as possible in the interests of the profession, and a desire to maintain and maintain membership in the profession. Therefore, auditor's dysfunctional behavior in conducting audit programs can also be influenced by their professional commitment. Empirical evidence of the influence of professional commitment to dysfunctional audit behavior is still limited (Silaban, 2009). Organizational commitment creates the power to balance the tendency for dysfunctional behavior. Someone who has a strong commitment to his organization and is willing to work hard to achieve the goals of his organization, will not accept dysfunctional behavior to achieve personal goals. This is contrary to someone who has a low commitment.

H2: Organizational commitment affects the behavior of decreasing audit quality.

\section{Effect of Locus of Control on Time Budget Pressure}

Brownell (1982) cited Gustati (2012) says that locus of control is the degree to which a person accepts personal responsibility for what happens to them. Locus of control is divided into two, namely internal and external locus of control. Internal locus 
of control refers to the perception that both positive and negative events occur as a consequence of actions or actions of oneself and under self-control, while external locus of control refers to the belief that an event has no direct relation to actions by oneself and is out of his control. Because perceived time budget pressure is the stress (stress) experienced by individual auditors caused their perceptions and judgments of time budget constraints in the implementation of the audit program, the auditor's locus of control can affect the perceived time budget pressure. In other words, whether the auditor feels the time budget as a pressure in the implementation of the audit program is influenced by individual auditor locus of control. In the psychology literature it is shown that individual locus of control influences the way they perceive a condition (Silaban, 2009).

H3a: Internal locus of control has an effect on time budget pressure.

H3b: External locus of control has an effect on time budget pressure.

\section{Effect of Organizational Commitment on Time Budget Pressure}

Auditors who have a high commitment to their organizations tend to try to work as well as possible to achieve company goals and they also consider the time budget is something that must be accepted because of the interests of the organization, while auditors who have low organizational commitment tend to consider strict audit time budget as pressure.

In order to obtain competent and sufficient audit evidence, before conducting the audit, the public accounting firm (KAP) first prepares an audit program and audit time budget. The audit program is a collection of audit procedures that must be carried out during the audit process, while the audit time budget is an estimate or estimated time allocated for the implementation of each audit procedure (Fleming, 1980; Otley and Pierce, 1996). The preparation of the audit program and audit time budget is a form of compliance of the Public Accounting Firm towards Audit Standards (SA 300 concerning Planning an Audit of Financial Statements), which requires the auditor to plan an audit so that the audit can be carried out effectively (Nugraha, 2016).

H4: Organizational commitment has an effect on time budget pressure.

\section{Effect of Time Budget Pressure on Audit Quality Decreasing Behavior}

To meet these audit standards, one of them is manifested in the form of audit time budgeting. Audit time budget is an estimate of the time allocated for the implementation of audit tasks in an assignment (Fleming, 1980). The audit time budget has the following benefits, as a basis for estimating audit costs, as a basis for dividing the duties of each team member, and as a basis for evaluating the performance of personnel auditors.

Intensive competition in the audit market requires KAP to be able to operate effectively and efficiently. KAP is required to collect sufficient competent evidence in meeting professional standards, and on the other hand KAP is required to carry out efficiency through controlling audit costs (Arens, 2011). Most of the audit costs are caused by the time of the audit, so to improve efficiency one of the efforts that is often taken by KAP is to tightly set the audit time budget (McNair, 1991). According to Kelley and Seiler, 1982; Cook and Kelley, 1988; Kelley and Margheim, 1990 A strict audit time budget can result in auditors feeling the pressure in implementing audit procedures because of the imbalance between the time available and the time needed to complete audit tasks (Nugraha, 2016). Strict audit time budget can cause the auditor to feel the pressure (stress) in doing work, and then can influence the attitudes, intentions and behavioral audits in the implementation of the audit program.

H5: Time budget pressure affects the audit quality decline behavior.

Time Budget Pressure mediates the effect of Locus of Control on Audit Quality Decreasing Behavior

When auditors who have locus of control face audit time budget pressures, they will be more susceptible to feeling stressed, and then affect auditor behavior to reduce audit quality in the implementation of audit programs (Nugraha, 2016). In this study the individual characteristics of the auditor studied were locus of control and auditor's 
commitment to the organization. Both of these individual auditor characteristics refer to the auditor's individual attitudes and beliefs that are thought to influence the auditor's perception of the audit time budget and audit behavior in the implementation of the audit program (Nugraha, 2016).

At the time of implementation of the audit program the auditor who has locus of control will feel with the time budget pressure given in completing the audit so that auditors who have criteria in dealing with various constraints and pressures in the assignment will make the auditor able to conduct behavior that decreases audit quality when doing audit program. Strict audit time budget can cause the auditor to feel the pressure in the implementation of audit procedures because of an imbalance between the time available and the time needed to complete the audit task, and then these conditions can encourage auditors to perform dysfunctional audit actions (Kelley and Seiler, 1982; Cook and Kelley, 1988).

H6a: Audit time budget pressure mediates the influence of internal locus of control on audit quality deterioration behavior.

H6b: Audit time budget pressure mediates the influence of external locus of control on audit quality deterioration behavior.

\section{Time Budget Pressure Mediates Organizational Commitment to Audit Quality Decreasing} Behavior

Choo (1986) notes that individual commitment is reflected in persistence even under stressful conditions. Mention that individuals who have organizational commitments will work better than those who are not committed. This finding will tend to have a high influence on audit quality decline behavior than auditors with high organizational commitment. At the time of the audit assignment conducted by the auditor, the auditor will experience pressure in the assignment carried out, namely the time budget pressure that makes the auditor can reduce audit quality, on the other hand the auditor also has an attachment to KAP which makes the auditor need professionals in conducting audit assignments. In addition, KAP is required to carry out efficiency through controlling audit fees. Most of the audit costs are caused by the time of the audit, so to increase efficiency one of the efforts that is often taken by KAP is to tightly set audit time budgets (Limawan et al, 2016).

H7: The audit time budget pressure mediates the influence of organizational commitment on audit quality reduction behavior.

\section{RESEARCH METHODOLOGY}

\section{Population and Samples}

The population are auditors in public accounting firms located in the provinces of West Sumatra, Riau and Riau Islands. The unit of analysis is the auditor at the level of junior, senior, supervisor, and partner auditors. Respondent criteria are auditors involved in the implementation of the audit program on the general audit of the company's financial statements conducted by KAP who have audit experience, in this study sample selection was carried out using the purposive sampling method.

\section{Data collection technique}

The method used in this research is by distributing questionnaires to the Office of Public Accountants conducted at Public Accountant Offices in the province of West Sumatra, Riau, and Riau Islands. This method is considered the most effective way to get research data with consideration of time efficiency, cost and authenticity of data. Each respondent was asked to choose one answer in a questionnaire that was in accordance with his perception among the alternative answers provided. The instructions for filling out the questionnaire are made as simple as possible, namely by putting a check mark $(\sqrt{ })$ or a cross $(\times)$ in the selected column.

\section{Data Type}

The types of data collected and processed are primary data obtained from the answers of partners, supervisors, senior auditors, and junior auditors, namely answers to a series of questions posed by researchers regarding locus of control, organizational 
commitment, audit quality reduction behavior, and time budget pressures. was hit by a public accounting firm. This questionnaire is addressed to the public accounting firm.

\section{Data source}

The data source of this study is the primary data source. Primary data sources are sources of data obtained directly from the original source (not through intermediary media). This study uses a questionnaire distributed to the public accounting firm (Directory Source of the Public Accounting Firm and Public Accountant 2018).

\section{Operational definition}

Audit Decreasing Behavior: can be defined as a reaction that is owned by someone towards everything that is seen, felt, and understood to be subsequently formed in actions and attitudes. Objectives to be achieved by the quality of audits to increase awareness of the key elements of audit quality within the Public Accountants, as well as facilitate greater dialogue between stakeholders on the element. Decreasing audit quality behavior is measured using the Silaban instrument (2009), using 10 questions with the scale used is a 1 to 5 point Likert scale.

Locus of Control: internal locus of control. Robbins (2008: 138) states that locus of control is how much one's belief in themselves determines their own destiny. A person's locus of control is distinguished by a person's point of view which is external locus of control and internal locus of control. Robbins (2008: 138) states that if individuals have an internal locus of control it means that these individuals are more convinced that they themselves are the determinant of their fate. This instrument variable is used by Gustati (2012). This questionnaire consists of 7 questions with the scale used is a Likert scale of 1 to 5 points.

External locus of control: is the feeling experienced by individuals that their behavior is determined by factors outside their control, individuals with external locus of control are individuals who believe that they cannot control events and results. Individuals who are more convinced that something happens to them because it is caused by forces outside themselves such as luck indicates that the individual has an external locus of control (Wintari, 2015). The variable of this instrument was used by Silaban (2009). This questionnaire consists of 16 questions with the scale used is a Likert scale of 1 to 5 points.

Organizational Commitment: The auditor's commitment to his profession is an important factor that influences the auditor's behavior in carrying out audit tasks (Silaban, 2009). These needs, after interacting with personal experiences and individual value systems, will determine expectations or goals in each behavior, before finally the individual determines what action to take, organizational commitment is measured using the instruments used by Nugraha (2016) using 6 questions with the scale used is a 1 to 5 point Likert scale.

Time Budget Pressure: the pressure experienced by the auditor at the time of the audit because of the limited time allocated to carry out all audit tasks is called time budget pressure (DeZoort and Lord, 1997). The auditor will feel the time pressure when carrying out the audit program due to the tight budget allocated audit time or an imbalance between available audit time budgets and real time needs to complete the overall audit program (Kelley and Seiler, 1982). Time budget pressure is measured using the Silaban instrument (2009) using 6 questions with the scale used is a 1 to 5 point Likert scale.

\section{Data analysis method}

Data analysis method is a method used by researchers in collecting research data. The method is a questionnaire, observation or observation interviews, tests and documentation (Arikunto, 2010: 160). The analytical method used in this study is a quantitative analysis method that is an analysis that uses numbers and statistical calculations to analyze a hypothesis and requires several analytical tools. By using quantitative methods, it is hoped that more accurate measurements of the responses given by respondents will be obtained, so that data in the form of numbers can be processed using statistical methods. The data analysis tool in this study uses Structural 
Equation Modeling-Partial Least Square (SEM-PLS) by using WarpPLS version 6.0 software. Another advantage of using PLS is that PLS can estimate the size of the model in validity and reliability, and use latent construct indicators.

\section{FINDINGS AND DISCUSSION}

Descriptive statistics are intended to analyze data based on the results obtained from respondents' answers to each variable measuring indicator. Descriptive statistics consist of mean, minimum, maximum, and standard deviation. Descriptive analysis of research variables can be seen in the table below.

Table 1. Descriptive Statistics

\begin{tabular}{lcccc}
\multicolumn{1}{c}{ Variable } & Mean & Min & Max & Std. Dev \\
\hline Locus of Control Internal & 23,55 & 14 & 32 & 3,651909 \\
\hline Locus of Control External & 52,23333 & 44 & 64 & 6,999677 \\
\hline Organizational Commitment & 18,63333 & 11 & 30 & 4,33342 \\
\hline Time Budget Pressure & 19,2 & 8 & 28 & 4,725696 \\
\hline Audit Decreasing Behavior & 25,41667 & 12 & 42 & 8,539622 \\
\hline
\end{tabular}

Outer Relation or Measurement Model Testing

Test results for construct validity and reliability. Outer model (outer relation or measurement model) defines how each indicator block is related to its latent variables. The measurement model or outer model with reflexive indicators is evaluated by covergent and discriminant validity from the indicator and composite reliability for the block indicator. The results of the outer model in this study are as follows:

Table 2. Outer/Measurement Model

\begin{tabular}{|c|c|c|c|c|}
\hline Construct & Range & AVE & $\begin{array}{l}\text { Composite } \\
\text { Reliability }\end{array}$ & $\begin{array}{c}\text { Crobach } \\
\text { Alpha }\end{array}$ \\
\hline Locus of Control Internal & $0,683-0,913$ & 0,532 & 0,855 & 0,837 \\
\hline Locus of Control External & $0,720-0,998$ & 0,911 & 0,976 & 0,985 \\
\hline Organizational Commitment & $0,710-0,982$ & 0,748 & 0,962 & 0,936 \\
\hline Time Budget Pressure & $0,705-0,877$ & 0,662 & 0,971 & 0,873 \\
\hline Audit Decreasing Behavior & $0,738-0,999$ & 0,636 & 0,952 & 0,974 \\
\hline
\end{tabular}

\section{Validity of Discrimination}

The correlation matrix in the table below shows an evaluation of the discriminant validity of the research instrument. The criteria for discriminant validity are fulfilled if the square root AVE is greater than the correlation coefficient between constructs in each column. The criteria used are square root average variance extracted (AVE), which is a diagonal column and given a bold letter (thick), the value must be higher than the correlation between latent variables in the same column (above or below). The results of discriminant validity in this study are presented in the table below:

Table 3. Correlations Latent Variables

\begin{tabular}{llllll}
\hline & LOCI & LOCE & \multicolumn{1}{c}{ KO } & \multicolumn{1}{c}{ TAW } & \multicolumn{1}{c}{ PPKA } \\
\hline LOCI & $\mathbf{( 0 . 6 8 8 )}$ & -0.246 & -0.158 & 0.013 & -0.234 \\
\hline LOCE & -0.246 & $\mathbf{( 0 . 9 8 6 )}$ & -0.057 & 0.115 & 0.096 \\
\hline KO & -0.158 & -0.057 & $\mathbf{( 0 . 8 7 9 )}$ & 0.158 & 0.651 \\
\hline TAW & 0.013 & 0.115 & 0.158 & $\mathbf{( 0 . 8 2 4 )}$ & 0.424 \\
\hline PPKA & -0.234 & 0.096 & 0.651 & 0.424 & $\mathbf{( 0 . 7 5 6 )}$ \\
\hline
\end{tabular}

\section{Testing the Mediation Effect}

The Time Budget Pressure testing procedure as the mediating variable of the relationship between locus of control and organizational commitment to Audit Quality Decreasing Behavior is as follows: Direct Effect Testing. Estimating direct effect locus of control and organizational commitment to audit quality reduction behavior (path c) 


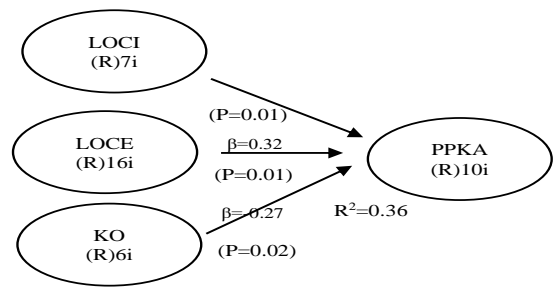

Figure 1. Direct effect

\section{Indirect Effect test}

Estimating simultaneous indirect effects with PLS SEM triangle Model namely locus of control behavior decreases audit quality, organizational commitment behavior decreases audit quality, (path c), locus of control time budget pressure, organizational commitment time budget pressure (path a), pressure time budget behavior decreases audit quality (line b).

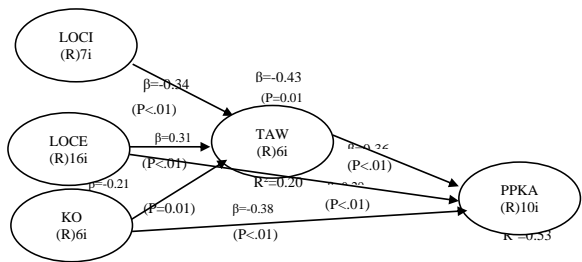

Figure 2. Indirect effect

The requirements for mediation effects that must be met are: (i) significant path c coefficient in the model (1), and (ii) path coefficients a and b must be significant in model (2). Taking conclusions about mediation is as follows:

a. If the path coefficient $c$ from the model estimation result (2) remains significant and does not change $(\mathrm{c}=\mathrm{c})$, the mediation hypothesis is not supported.

b. If the path coefficient $c$ value decreases $(c<c)$ but remains significant then the form of mediation is partial mediation.

c. If the path coefficient $\mathrm{c}$ value decreases $(\mathrm{c}<\mathrm{c})$ and becomes insignificant, the form of mediation is full mediation.

From the direct effect / model (1) and indirect effect model (2) tests above, the path test results are presented in the table below:

Table 4. Direct dan Indirect Effect

\begin{tabular}{lcccc}
\hline \multirow{2}{*}{ Lane } & \multicolumn{2}{c}{ Direct effect } & \multicolumn{2}{c}{ Indirect effect } \\
\cline { 2 - 5 } & Koef & $\mathbf{P}_{\text {value }}$ & Koef & $\mathbf{P}_{\text {value }}$ \\
\hline LOCI PPKA & -0.262 & 0.010 & -0.432 & 0.010 \\
\hline LOCE PPKA & 0.324 & 0.010 & 0.286 & $<0.001$ \\
\hline KO PPKA & -0.273 & 0.020 & -0.377 & $<0.001$ \\
\hline LOCI TAW & & & -0.343 & $<0.001$ \\
\hline LOCE TAW & & & 0.314 & $<0.001$ \\
\hline KO TAW & & & -0.211 & 0.010 \\
\hline TAW PPKA & & & 0.358 & $<0.001$ \\
\hline
\end{tabular}

\section{Testing the Mediation Model}

The results of testing the mediation model are presented in the previous subchapter which shows the results of the estimation of the direct effect and indirect effect criteria of the goodness of it. The provisions of the fit indices and $\mathrm{P}$ value model that show 3 fit indicators, namely average path coefficient (APC), average R-squared (ARS), and average variance inflation factor (AVIF) must be met if the P value for APC and ARS is smaller than 0, 05 or significant. In addition, AVIF as a multicollinearity indicator must be smaller than 5 . And the results of testing the goodness of fit in this study are presented in the following table: 
Table 5. Goodness of Fit

\begin{tabular}{ccccc}
\hline Lane & \multicolumn{2}{c}{ Direct effect } & \multicolumn{2}{c}{ Indirect effect } \\
\cline { 2 - 5 } & Koef & P $_{\text {value }}$ & Koef & P $_{\text {value }}$ \\
\hline APC & 0.278 & $<0.001$ & 0.349 & $<0.001$ \\
\hline ARS & 0.496 & $<0.001$ & 0.345 & $<0.001$ \\
\hline AVIF & 1.342 & $<5$ & 1.081 & $<5$ \\
\hline
\end{tabular}

The results above show that the criteria for goodness of fit have been fulfilled, namely the APC and ARS values are statistically significant and AVIF is less than 5 . The results above indicate that the requirements for testing mediation models are accepted.

Table 6. Score of VAF

\begin{tabular}{lllll}
\hline \multicolumn{1}{c}{ Lane } & \multicolumn{1}{c}{$\mathbf{a} \mathbf{x} \mathbf{b}(\mathbf{1})$} & \multicolumn{1}{c}{$(\mathbf{a} \mathbf{x} \mathbf{b})+\mathbf{c}(\mathbf{2})$} & \multicolumn{1}{c}{ VAF=(1)/(2)x $\mathbf{1 0 0}$} & $\mathbf{E f f e c t}$ \\
\hline LOCI->TAW->PPKA & $-0.343 \times 0.358=-0.123$ & $-0.123+-0.262=-0.385$ & $20 \%<31.94 \%<80 \%$ & Partial mediasi \\
\hline LOCE->TAW->PPKA & $0.314 \times 0.358=0.112$ & $0.112+0.324=0.436$ & $20 \%<25.69 \%<80 \%$ & Partial mediasi \\
\hline KO-> TAW->PPKA & $-0.211 \times 0.358=-0.076$ & $-0.076+-0.273=-0.349$ & $20 \%<21.77 \%<80 \% \quad$ Partial mediasi
\end{tabular}

Notes:

$a=$ path coefficient value of predictor variable to mediator, with significance $\mathrm{P}<0.05$

$\mathrm{b}=$ mediator variable value coefficient path to criterion, with significance $\mathrm{P}<0.05$

$\mathrm{c}=$ the path value of the predictor variable coefficient on the criterion variable before entering the mediator variable on the model

Based on VAF calculations to test the effect of time budget pressure variables as a mediator the effect of internal locus of control on audit quality decline behavior is 0.3194 or $31.94 \%$, the influence of time budget pressure variables as mediating the effect of external locus of control on audit quality reduction behavior is 0.2569 or $25.69 \%$, and the influence of time budget pressure variable as an evaluation of the effect of organizational commitment on the behavior of audit quality decline is 0.2177 or $21.77 \%$. From these results it can be concluded that time budget pressure has a partial mediating effect (Sholihin and Ratmono, 2013: 82).

\section{Discussion}

This hypothesis has statistical support. This shows that auditors who work at KAP have high internal locus of control so that they tend not to decrease the quality of audit behavior, auditors who work at KAP believe that everything achieved by an individual is the result of individual effort, and has confidence that everything is the result of own effort and effort so that the auditor is more trying and working hard to achieve certain results. Individuals who have internal locus of control tend to associate results or outcomes with their business ventures or they believe that events are under their control or control and they are committed to greater organizational goals than individuals who have external locus of control (Silaban, 2009 ).

This auditor who has an Internal LOC believes that he has great potential to determine his own destiny, regardless of whether there is support or lack of support from other parties. Individuals like this have a high work ethic, enduring all kinds of difficulties both in their lives and in their work. Although there is a feeling of worry in him, but these feelings are relatively small compared to the enthusiasm and courage to oppose himself so that people like this never want to escape from every problem at work (Gustati, 2012). This will make the auditor's performance better. Because the auditor is not only responsible for himself, but also to the client, the institution where he works, and users of the audit report. Auditors with good internal locus of control can make audit work carried out more conceptualized and structured in order to achieve good results, auditors are able to provide good work results in order to achieve the desired success so that auditors with high internal locus of control will have a tolerance that low on acceptance of audit quality deterioration behavior. The results of this study support the results of research conducted by Wijayanti (2009); and Wintari (2015).

This hypothesis has statistical support. This shows that auditors who work at KAP believe that luck and external factors are oneself in determining the success and success of a job or in a career. External locus of control tends to do something with no 
seriousness, less hard work, always assisted in completing a job, lack of confidence in one's own abilities, and achieving something desired by acquaintances or friends is more important than ability and effort so as to make individuals with External locus of control wants to complete a job less responsibly and quickly without considering success and getting good results in a job / assignment. The findings of this study indicate that auditors who have external locus of control tend to accept the behavior of audit quality deterioration in the implementation of the audit program. Individuals who have an external locus of control believe in successes and failures beyond their control or ability for the conditions or circumstances they face. They tend to choose emotionally focused strategies in overcoming an obstacle. They tend to choose emotionally focused strategies that are realized through the act of decreasing audit quality to deal with these obstacles.

This hypothesis has statistical support. This shows that auditors who have high commitment to their organizations are less likely to accept the behavior of decreased audit quality in the implementation of the audit program compared to auditors who have low commitment to the organization. In other words, the higher the commitment of the auditor to the organization, the lower the acceptance of audit quality decline behavior. Organizational commitment creates the power to balance the tendency to behave in a decline in audit quality. Someone who has a strong commitment to the organization and is willing to work hard to achieve the goals of the organization, will be less accepting of the deterioration of audit quality to achieve personal goals. This is in contrast to someone who has a low commitment.

Individuals who have a high commitment will have a level of absence (abseinteism) and low turnover with a high commitment, can reduce the tendency for them to actively seek other positions. Auditors who have a high commitment to the KAP, they will have a hard effort and will have a better performance, organizational commitment creates the power to balance the tendency of audit quality decline (Triono et al., 2012). Auditors who are highly committed to their organizations have a strong desire to defend themselves in the organization. They tend to try to follow all the rules of the organization and strive for organizational success. They prioritize the interests of the organization rather than personal interests. Conversely, someone who has a low organizational commitment is more likely to see dysfunctional behavior as something that is acceptable, for personal gain.

The results of this study indicate that auditors who have a high commitment to the organization tend to avoid taking action to reduce audit quality in the implementation of the audit program compared to auditors who have a low commitment to the organization. Thus, the higher the auditor's commitment to the organization, the lower the acceptance of audit quality decline behavior.

This hypothesis has statistical support. This shows that the internal auditor's locus of control has an influence on the auditor's confidence in exercising control over the time budget constraints faced in the implementation of the audit program. The higher the internal auditor's locus of control, the smaller the time budget pressure felt by the auditor in the audit assignment, and vice versa the lower the internal auditor's locus of control, the higher the pressure felt in the audit assignment.

The results of this study indicate that auditors working in the provinces of West Sumatra, Riau, and Riau Islands have high internal locus of control so that they tend to consider time budget pressure is not a barrier or pressure in audit assignments conducted by KAP. This shows that auditors with high internal locus of control will be able to control the pressure they experience because auditors who have internal locus of control have personalities who work hard and are able to control pressures or obstacles in audit assignments, so that auditors with internal locus of control The high level will be able to control situational factors, namely the time when doing an audit work. This can make the work of auditors with internal locus of control run well so that they are able to control the pressure that is obtained and the time of the audit, so it tends not to carry out behavioral actions to reduce audit quality. The time budget pressure felt by the auditor in the audit assignment can be influenced by the auditor's response, that is, the auditor's perception and evaluation of the time budget allocated for the audit program is influenced by the individual characteristics of the locus of control auditor, so 
the higher the internal auditor's locus of control, the lower the time budget pressure (Silaban, 2009).

This hypothesis has statistical support. This shows that auditors who have external locus of control tend to perceive time budgets as pressure in implementing the audit program compared to auditors who have internal locus of control. Brownell (1982) cited by Gustati (2012) said that locus of control is the degree to which a person accepts personal responsibility for what happens to them, external locus of control refers to the belief that an event has no direct relationship with actions by oneself and is out of her control. Psychology literature explained that individuals who have external locus of control believe that they have limited ability to exercise control over circumstances. They tend to have feelings of anxiety, easy stress, and depression. Thus, auditors who have an external locus of control tend to view the time budget as pressure in implementing the audit program.

Such conditions occur due to demands to the auditor to complete the audit task in a little time. While they have limited ability to budget the time allocated for conducting audits. This study provides support for the results of research conducted by Silaban (2009); Sudirjo (2013); Yuliani et al (2016); and Nugraha (2016), that external locus of control has an influence on time budget pressure. This result supports the theory of work stress model, that auditors who have external locus of control tend to experience work stress at a higher level compared to auditors who have internal locus of control. Audit time budget pressure is the stress felt by the auditors in implementing the audit program as a result of their assessment or perception of the time budget. Work stress model theory states that stress experienced by a person in the work environment is influenced by individual characteristics. Thus, the auditor's locus of control, which is a personal characteristic of the auditor, gives an influence on audit time budget stress (stress) in the implementation of the audit program (Silaban, 2009).

This hypothesis has statistical support. This shows that auditors who have high commitment to their organizations tend to feel less time budget pressure at a high level in the implementation of the audit program compared to auditors who have a low commitment to the organization. So the higher the commitment of the auditor to the organization, the lower the audit time budget pressure felt.

Organizational commitment creates the power to balance the tendency to behave in a lower quality audit. The high organizational commitment of the auditor tends to avoid the behavior of decreasing audit quality even though there is a disturbing situational factor namely time budget pressure in audit assignments. Auditors who have a low commitment to their organizations are more easily feel stressed when experiencing audit budget pressure, which will then have an impact on deviant behavior. They tend not to be in line with the goals and values of the organization, because they are more concerned with personal interests.

This hypothesis has statistical support. This shows that auditors working in the provinces of West Sumatra, Riau, and Riau Islands feel that time budget pressure is a factor in the behavior of audit quality deterioration. then it can influence the attitudes, intentions and behavior of the audit in the implementation of the audit program.

Strict audit budget time pressures can cause auditors to feel pressure in carrying out audit procedures due to an imbalance between the time available and the time needed to complete the audit task. The results showed that the more increased audit time budget pressure felt in the implementation of the audit program, the increasing the tendency for auditors to take action to reduce audit quality in completing audit tasks. Acceptance of the hypothesis can be described as follows, in general the auditor feels a plan to complete the audit task within the predetermined time budget.

The auditor considers the implementation of audit tasks is difficult or impossible to complete within the specified time budget, so to meet the time budget they take a shortcut by taking action to reduce audit quality in the audit program implementation. This hypothesis gives the result that there is a time budget pressure mediating the effect of internal locus of control on the behavior of audit quality deterioration. This hypothesis has statistical support. This shows that audit time budget pressure mediates the influence of locus of control on audit quality deterioration behavior. The indirect effect of internal locus of control on audit quality reduction behavior is smaller but through time budget pressure based on the results of mediation variable testing, audit 
time budget pressure mediates the effect of locus of control on audit quality decline behavior. Although the indirect effect is smaller than the direct effect, the audit time budget pressure can be as a mediator, so the hypothesis is accepted.

KAP auditors working in the provinces of West Sumatra, Riau, and Riau Islands that have high internal locus of control tend not to accept audit quality deterioration behavior, but with time budgetary pressure can mediate the effect of internal locus of control on the behavior of audit quality decline supported with statistical test results. This is in accordance with research conducted by Chen (2008) who tested the effect of locus of control and work stress behavior, job satisfaction, and performance.

The results showed that one of the aspects of an auditor's personality as measured by a higher internal locus of control tended to have higher levels of work stress, job satisfaction, and practical performance. One cause of auditor stress is time budget pressure in audit assignments (Yuliani., 2016).

Based on the results of testing mediation variables, audit time budgetary pressure mediates the effect of locus of control on audit quality deterioration behavior. Although the indirect effect is smaller than the direct effect, the audit time budget pressure can be as a mediator, so the hypothesis is accepted.

Acceptance of this hypothesis supports the theory of work stress models that the causes of stress faced by individuals in the work environment can cause individuals to feel pressure (stress) in doing work, and can further influence individual attitudes, intentions and behavior. When auditors who have external locus of control face time budget pressure, they are more prone to feel stressed, and subsequently affect the behavior of auditors to reduce audit quality in the audit program implementation.

This hypothesis provides the result that there is a budgetary pressure when mediating the effect of organizational commitment to audit quality deterioration behavior. This hypothesis has statistical support. This shows that audit time budget pressure mediates the influence of organizational commitment on audit quality deterioration behavior. The indirect effect of organizational commitment on audit quality deterioration behavior through audit time budget pressure is not stronger than its direct influence. Auditors who tend to have a low commitment to their organization based on answers to research questionnaires tend to feel time budget pressure and accept the behavior of audit quality deterioration.

There are auditors who have a high commitment to their organizations feel the pressure of the audit time budget and accept the behavior of audit quality deterioration. This is the cause of the indirect effect of organizational commitment on the behavior of audit quality decline is smaller than the direct influence. According to the theory of work stress models that work-related stress (work stress) which states that the causes of stress faced by the auditor can cause the auditor to feel pressure (stress) in doing work, and subsequently can affect the attitudes, intentions and behavior of the auditor. Auditors who have a low commitment to their organizations face time budget pressure, will be more prone to feel stress, and subsequently influence the auditor to conduct audit quality decline in the conduct of the audit program. Interaction between organizational commitment as an internal factor and audit time budget pressure as a situational factor, can cause stress felt by the auditor which then influences his behavior.

\section{CONCLUSION AND SUGGESTIONS}

Internal locus of control and organizational commitment negatively affect time budget pressure while external locus of control has a positive effect on time budget pressure. This shows that auditors who have an external locus of control tend to perceive time budgets as pressure and conversely auditors who have internal locus of controls do not perceive time budgets as pressure, and the higher the commitment the auditor has to his organization the lower the perceived time budget pressure.

External locus of control and audit time budget pressure have a positive effect on audit quality deterioration behavior while internal locus of control and organizational commitment have a negative effect on audit quality deterioration behavior. This shows that auditors who have external locus of control tend to accept audit quality 
deterioration behavior rather than auditors who have internal locus of control, the higher the commitment of the auditor to the organization, the lower the acceptance of decreased audit quality behavior and the higher time budget pressure the higher the acceptance of the decline in audit quality behavior. Time budgetary pressure mediates the effect of locus of control and organizational commitment on audit quality deterioration behavior.

This research is inseparable from limitations and weaknesses. Limitations that need to be corrected in subsequent studies are: The measurement instruments of this research variable all use instruments from previous researchers that are adapted to different languages than the original, so that there may be weaknesses in the translation of instruments that cause changes in the meaning that actually wants to be achieved. The limitation of this study is research scope limited for auditors province West Sumatra, Riau, and Riau Islands, so that further research should be carried out with a broader scope.

Based on the results of testing the hypothesis and the discussion and conclusions described earlier, the authors provide the following suggestions: It is suggested to the next researcher to be able to explain the purpose of the questionnaire content with a language that is easier to understand so that the filling of the questionnaire by the next respondent can be as expected. Future research can use respondents who are more varied and expand the scope of the sample used. Subsequent research can be carried out using other variables that can influence the occurrence of audit quality reduction behavior. For example by adding testing factors in terms of internal auditor characteristics such as (self esteem, need for approval, need for achievement as well as competitive type behavior) that are likely to cause the behavior of audit quality decline.

\section{REFERENCES}

Aisyah, R. N., Sukirman., dan Suryandini,D. 2014. Faktor-Faktor yang Mempengaruhi Perilaku Disfungsional Audit: Penerimaan Auditor BPK RI Jateng. Accounting Analysis Journal, 3 (1).

Arens, A.A., Elder, R.J., Beasley, M.S. (2011). Auditing dan Pelayanan Verifikasi: Pendekatan Terpadu, alih bahasa oleh Tim Dejakarta, edisi kesembilan, Jakarta: Indeks.

Arikunto, Suharsimi. 2010. Prosedur Penelitian: Suatu Pendekatan Praktik. Edisi Revisi 2010. Rineka Cipta:Jakarta

CPAB 2015 Public Report on Annual Inspections of the Quality of Audits in Canada. (2016). [pdf] CPAB. Available at: http://www.cpabccrc.ca/Documents/Annual\%20Reports/CPAB_2015_PR_Highlights_EN.pdf [Accessed 16 Sep. 2016].

CPAB Public Report on 2015 Inspections of Canada's Big Four Accounting Firms. (2015). [pdf] CPAB, p.2. Available at: ccrc.ca/Documents/Annual\%20Reports/CPAB_2015_Big_Four_Report_Highlight s_EN_Final.pdf [Accessed 16 Sep. 2016].

DeAngelo, L.E., 1981. "Auditor Size and Auditor Quality", Journal of Accounting and Economics, Vol. 3, No. 3, pp. 183-199.

Diana, Haugesti. 2016. Pengaruh Tekanan Anggaran waktu, Resiko Audit, Locus of Control, dan Komitmen Profesional terhadap Perilaku Penurunan Kualitas Audit (Studi Empiris di BPK RI Provinsi Riau) (tesis). Pekanbaru: Universitas Riau.

Directory Kantor Akuntan Publik dan Akuntan Publik. 2017

Fahmi, Irham. 2014. Perilaku Organisasi (Teori, Aplikasi, dan Kasus). Cetakan kedua Juli 2014. Bandung: Alfabeta.

Ferris, K. 1981. "Organizational Commitment and Performance in A Professional Accounting Firm." Accounting: Organizations and Society 6: 317-325. 
Gordon, L. M., Graham, S. 2006. Attribution theory, The Encyclopedia of Human Development. Thousand Oaks: Sage Publications, 1, p.142-144.

Gustati. 2012. Persepsi Auditor Tentang Pengaruh Locus of Control Terhadap Penerimaan Perilaku Disfungsional Audit (Survey pada Auditor BPKP Perwakilan Provinsi Sumatera Barat). Jurnal Akuntansi \& Manajemen, Vol. 7 No. 2 Desember 2012 ISSN 1858-3687, p.46-68.

Harini. D., Wahyudin, A., Anisykurlillah., I. 2010. Analisis Penerimaan Auditor Atas Dysfunctional Audit Behavior: Sebuah Pendekatan Karakteristik Personal Auditor. Simposium Nasional Akuntansi (SNA) XIII Purwokerto.

Irawati, Y., Petrolina, A. T., dan Mukhlasin. 2005. Hubungan Karakteristik Personal Auditor Terhadap Tingkat Penerimaan Penyimpangan Perilaku Dalam Audit. Simposium Nasional Akuntansi VIII Solo.

Jayanti, Nyoman. 2017. Pengaruh Locus of control, komitmen profesionaldan stress kerja terhadap reduksi kualitas audit. Journal. Bali.

Kelley, T. and Margheim, L. 1990. The Impact of Time Budget Pressure, Personality and Leadership Variabel on Dysfunctional Behavior. Auditing: A Journal of Practice and Theory, Vol. 9. No. 2, p21-41.

Kementerian Keuangan Republik Indonesia. 2017. Sekretariat Jenderal. Pusat Pembinaan Profesi Keuangan. Indeks Kualitas Profesi Akuntan Publik Di Indonesia.

Kholidiah dan Murni, S. A. 2014. Analisis Faktor-Faktor Yang Berpengaruh Terhadap Terjadinya Penghentian Prematur (Prematur Sign Off) Atas Prosedur Audit (Studi Kasus Pada Kantor Akuntan Publik Di Jawa Timur). Simposium Nasional Akuntansi XVII Lombok.

Kreitner, R., and Kinicki, A. 2000. Organizational Behavior. Fifth Edition. Mc Graw-Hill.

Kuncoro, M. 2013. Metode Riset untuk Bisnis dan Ekonomi. Jakarta: Erlangga. Kurnia. 2009. Pengaruh Tekanan Waktu Audit dan Locus of Control Terhadap Tindakan yang Menurunkan Kualitas Audit. Ekuitas, Vol. 15 No. 4 Desember 2011 ISSN 1411-0393, p.456- 476.

Latan,H., dan Ghozali, Imam. 2012. Partial Least Square: Konsep, Teknik dan Aplikasi SmartPLS 2.0 M3. Semarang: Badan Penerbit Universitas Diponegoro

Lazarus, R. S. 1995. Psycological Stress in the Work Place. In: Crandall, R and Perrewe, P. L., editors. Occupational Stress: A Handbook. Washington, DC: Taylor \& Francis, p.3-14.

Limawan, Y. F., dan Ni Putu Sri Harta Mimba. 2016. Pengaruh Komitmen Organisasi, Locus of Control dan Tekanan Anggaran Waktu Audit pada Penerimaan Underreporting of time. E-Jurnal Akuntansi Universitas Udayana. Vol.15.1 April (2016): 799-831.

Malone, C. F, dan R. W Robberts. 1996. Factors Assosiated With The Incidence of Reduced Audit Quality Behaviors. Auditing: A Journal Practice and Theory, Vol. 15. No 2, p.49-64.

Manullang, Asna. 2010. Pengaruh Tekanan Anggaran Waktu dan Resiko Kesalahan Terhadap Penurunan Kualitas Audit (The Influence of Time Budget Pressure and Risk of Error to Reduced Audit Quality). Fokus Ekonomi, Vol. 5 No. 1 Juni 2010, p.81- 94.

McNair, C.J. 1991. Proper Compromises: The Management Control Dilemma in Public Accounting and Its Impact on Auditor Behavior. Accounting, Organizations and Society, Vol. 16 No. 7, p.635-653. 
Nadirsyah dan Zuhra I. M. 2009. Locus of Control, Time Budget Pressure dan Penyimpangan Perilaku Dalam Audit. Jurnal Telaah \& Riset Akuntansi, Vol. 2 No. 2 Juli 2009, p.104-116.

Nugraha, D. H. 2016. Pengaruh Locus of Control dan Komitmen Organisasi terhadap Perilaku Audit melalui Tekanan Anggaran Waktu Audit sebagai Variabel Mediasi (Studi Empiris di Kantor Akuntan Publik Bali) (tesis). Bali: Universitas Udayana.

Otley, D. T., and Pierce, B. J. 1996. Audit Time Budget Pressure: Consequence and Antecendents. Accounting, Auditing and Accountability Journal, Vol. 9 No. 1, p.3158.

Pristiyanti. i. Ruly. 2012. Persepsi pegawai instansi pemerintahan mengenai faktorfaktor yang mempengaruhi fraud di sektor pemerintahan. Jurnal. Fakultas ekonomi. Universitas negeri semarang. Indonesia.

Robbins, S. P. dan Timothy, A. J. 2015. Perilaku Organisasi. Edisi 16. (Ratna Saraswati dan Febriella Sirait, Pentj). Jakarta: Salemba Empat).

Rotter, J. B. 1966. Generalized Expectancies For Internal Versus External Control of Reinforcement. Psychological Monographs, Vol. 80, p.1-28.

Shapeero, M., Koh, H.C., and Killough, L.N. 2003. Underreporting and Premature Signoff in Public Accounting. Managerial Auditing Journal. Vol. 18. No. 6/7. pp. 478-489.

Sholihin, Mahfud dan Ratmono, Dwi. (2013). Analisis SEM-PLS dengan Wrap PLS 3.0 Untuk Hubungan Nonlinear dalam Penelitian Sosial dan Bisnis Yogyakarta: Penerbit ANDI.

Silaban, Adanan. 2009. Perilaku Disfungsional Auditor Dalam Pelaksanaan Program Audit (Studi Empiris di Kantor Akuntan Publik) (disertasi). Semarang: Universitas Diponegoro.

Simanjuntak, Piter. 2008. Pengaruh Time Budget Pressure dan Resiko Kesalahan Terhadap Penurunan Kualitas Audit (Reduced Audit Quality) (Studi Empiris pada Auditor KAP di Jakarta (tesis). Semarang: Universitas Diponegoro.

Suartana, I Wayan. 2010. Akuntansi Keperilakuan, Teori dan Implementasi. Denpasar: Andi Yogyakarta.

Sugiyono, DR. 2009. Metode Penelitian Bisnis. Alfabeta: Bandung

Sudirjo, Frans. 2013. Perilaku Auditor Dalam Pelaksanaan Program Audit (Studi Empiris pada Kantor Akuntan Publik di Semarang). Serat Acitya-Jurnal Ilmiah. (UNTAG) Semarang.

Suryanita Weningtyas., Doddy S., dan Hanung, T. 2006. Penghentian Prematur Atas Prosedur Audit. Simposium Nasional Akuntansi IX Padang.

Tandiontong, M. 2016. Kualitas Audit dan Pengukurannya. Alfabeta

Tanjung, Roni. 2013. "Pengaruh Karakteristik Personal Auditor dan Time Budget Pressure Terhadap Perilaku Disfungsional Auditor (Studi Empiris pada KAP di Kota Padang dan Pekanbaru)". Padang: Universitas Negeri Padang.

Trevino, L. K., 1986. "Ethical Decision Making in Organizations: A Person Situation Interactionist Model”. Academy of Management Review. Vol. 11 No. 3. pp. 601617.

Triono, H., Anton, dan Setiawan. D. 2012. Pengaruh Locus of Control, Komitmen Organisasional, dan Posisi Terhadap Penerimaan Perilaku Disfungsional Audit (Studi Kasus pada Kantor Akuntan Publik di Kota Semarang). Prosiding Seminar Nasional Forum Bisnis \& Keuangan I, ISBN: 978-602-17225-0-3, p.152-165.

Wijayanti, Provita. 2009. Pengaruh Karakteristik Personal Auditor Terhadap Penerimaan Perilaku Disfungsional Audit (Studi Empiris pada Auditor Pemerintah 
Yang bekerja di BPKP Perwakilan Jawa Tengah dan Daerah Istimewa Yogyakarta). JAI, Vol.5, No.2, Juli 2009, p.251-271.

Wintari, Intan. 2015. Pengaruh Tekanan Anggaran Waktu, Locus of Control, dan Komitmen Profesional Pada Perilaku Penurunan Kualitas Audit (tesis) Denpasar: Universitas Udayana.

Yuliani, G. M. D. O., dan Gede Juliarsa. 2016. Tekanan Anggaran Waktu Memoderasi Locus Of Control Internal Pada Perilaku Underreporting Of Audit Time. E-Jurnal Akuntansi Universitas Udayana. Vol.15.3. Juni (2016): 1856-1885. 